\title{
PENERAPAN MODEL PEMBELAJARAN PROBING- PROMPTING DAN DIRECT INSTRUCTION MENGGUNAKAN MEDIA PETA KONSEP UNTUK MENINGKATKAN HASIL BELAJAR SISWA PADA MATERI HIDROKARBON
}

\author{
Arifin Suhendra ${ }^{1}$ dan Ani Sutiani ${ }^{2}$ \\ 1)Alumni Prodi Pendidikan Kimia FMIPA Universitas Negeri Medan \\ 2)Dosen Jurusan Kimia FMIPA Universitas Negeri Medan. \\ Email : asr.sutiani@gmail.com
}

Diterima 22 Juni 2017, disetujui untuk publikasi 02 Agustus 2017

\begin{abstract}
Abstrak Penelitian ini bertujuan untuk mengetahui penerapan model pembelajaran Probing-Prompting (PP) dan Direct Instruction (DI) dengan menggunakan media peta konsep pada pokok bahasan hidrokarbon. Populasi penelitian ini seluruh siswa kelas X semester Genap SMA Negeri 10 Medan, dengan sampel penelitian terdiri dari dua kelas, yaitu kelas pertama sebagai kelas eksperimen dengan menerapkan model pembelajaran PP, dan kelas kedua sebagai kelas kontrol dengan model pembelajaran DI. Kedua kelas sama-sama menggunakan media peta konsep. Instrumen yang digunakan dalam penelitian ini disusun dalam bentuk objective test yang telah dianalisis dan dinyatakan memenuhi syarat secara expert judgement, tingkat kesukaran, daya pembeda, dan reliabilitas. Hasil penelitian menunjukkan bahwa peningkatan hasil belajar dengan penerapan model pembelajaran PP-peta konsep sebesar 54,28\%, sedangkan peningkatan hasil belajar dengan penerapan model pembelajaran DI-peta konsep sebesar 44,34\%. Uji hipotesis dengan uji t menunjukkan bahwa hasil belajar siswa yang diajarkan dengan model pembelajaran PP-peta konsep lebih tinggi dibandingkan dengan siswa yang diajarkan dengan model pembelajaran DI-peta konsep untuk materi Hidrokarbon.
\end{abstract}

Kata kunci : Probing Prompting, Direct Instruction,

Peta Konsep, hasil belajar, Hidrokarbon. 


\section{Pendahuluan}

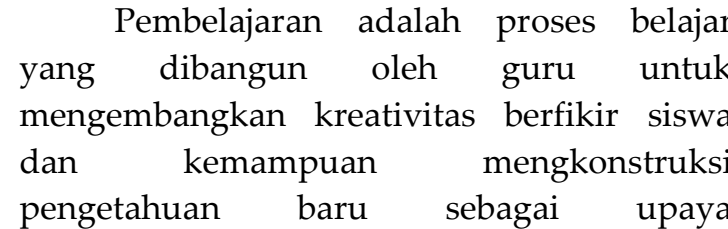
meningkatkan penguasaan yang baik terhadap materi pelajaran (Sagala, 2003). Kegiatan pembelajaran dituntut untuk menggunakan model pembelajaran dan media pembelajaran yang sesuai dengan pokok bahasan yang diberikan. Dalam proses pembelajaran siswa dituntut untuk lebih menguasai konsep dari pokok bahasan yang diberikan. Upaya peningkatan kualitas pendidikan tidak dapat berhasil dengan maksimal tanpa didukung adanya peningkatan kualitas pembelajaran. Tujuan umum dalam proses pembelajaran adalah penguasaan materi secara optimum oleh siswa yang dikenal dengan belajar tuntas (Astuti, 2011).

Ada berbagai macam model yang diterapkan dalam proses pembelajaran. Suatu model pembelajaran yang cocok diterapkan pada pokok bahasan tertentu belum tentu cocok diterapkan pada pokok bahasan yang lain. Untuk itu seorang guru perlu memilih model yang paling sesuai untuk materi tertentu, sehingga siswa akan memperoleh hasil belajar yang maksimal. Model pembelajaran merupakan salah satu faktor yang paling penting dalam proses pembelajaran, karena setiap siswa pada dasarnya mempunyai gaya belajar yang berbeda-beda (Huda, 2014). Oleh karena itu kompetensi guru dalam menentukan model pembelajaran secara tidak langsung mempengaruhi kemampuan siswa dalam memahami konteks materi pembelajaran yang disampaikan (Sagala, 2003 ; Huda, 2014)

Pada dasarnya proses belajar mengajar merupakan proses komunikasi antara guru dengan siswa. Proses pembelajaran dapat dikatakan berhasil apabila siswa mencapai kompetensi yang diharapkan, karena hal itu merupakan cerminan dari kemampuan siswa dalam menguasai suatu materi. Hal ini tidak terlepas dari kemampuan guru dalam memilih dan menggunakan model pembelajaran dan media yang tepat dan efektif, bila model pembelajaran dan media yang digunakan guru tidak tepat dan tidak efektif maka akan menyebabkan rendahnya hasil belajar siswa (Djamarah dan Zain, 2006). Selain ketidaktepatan model pembelajaran dan media yang digunakan, sikap siswa yang pasif saat proses pembelajaran juga menjadi salah satu faktor penyebab rendahnya nilai siswa. Arikunto (2009) menyatakan usaha dan kebiasaan belajar siswa merupakan faktor yang diperhitungkan dalam penilaian.

Berdasarkan hasil observasi di kelas $X$ SMAN 10 Medan, proses pembelajaran kimia secara umum masih berpusat pada guru dengan pengajaran bersifat verbal dan kurangnya variasi dalam proses pembelajaran kimia, sehingga selama proses pembelajaran, siswa tampak pasif, dan cenderung merasa bosan karena siswa hanya menerima apa yang diberikan oleh guru. Hasil pengamatan di kelas serta wawancara dengan guru dan siswa, dapat diidentifikasikan permasalahan yang terjadi adalah sebagai berikut : (1) perlu adanya pemanfaatan media pembelajaran untuk memotivasi siswa dalam mempelajari materi kimia, (2) siswa perlu dirangsang untuk aktif bertanya agar proses pembelajaran dapat berlangsung dengan aktif, 3) perlu adanya penggunaan model pembelajaran yang disesuaikan dengan pokok bahasan dan kompetensi siswa sehingga dapat meningkatkan hasil belajar siswa.

Berdasarkan uraian di atas maka perlu dicari alternatif model dan media pembelajaran yang lebih melibatkan siswa secara aktif dalam proses pembelajaran kimia. Salah satu alternatif yang digunakan adalah dengan menggunakan pembelajaran model probing-prompting menggunakan media peta konsep. Model pembelajaran probingprompting (PP) merupakan salah satu model pembelajaran dengan cara guru menyajikan serangkaian pertanyaan yang sifatnya menuntun dan menggali sehingga terjadi proses berpikir yang mengaitkan 
pengetahuan setiap siswa dan pengalamannya dengan pengetahuan baru yang sedang dipelajari (Widyastuti dkk, 2014). Dengan model pembelajaran ini proses tanya jawab dilakukan dengan menunjuk siswa secara acak sehingga setiap siswa mau tidak mau harus berpartisipasi aktif, siswa tidak bisa menghindar dari prses pembelajaran, setiap saat ia bisa dilibatkan dalam proses tanya jawab (Pristiadiutomo, 2010).

Model probing-prompting bertujuan untuk memperoleh sejumlah informasi yang telah ada pada diri siswa agar dapat digunakan untuk memahami pengetahuan atau konsep baru sehingga model ini dapat membuat siswa berperan aktif dalam pembelajaran karena setiap siswa dituntut untuk dapat berpartisipasi dalam proses pembelajaran terutama dalam hal menjawab pertanyaan yang diajukan oleh guru (Fitroh, 2012). Dalam model pembelajaran ini proses tanya jawab dilakukan dengan menunjukan siswa secara acak sehingga setiap siswa harus berpartisipasi aktif, dan siswa tidak bisa menghindar dari proses pembelajaran, karena setiap saat dilibatkan dalam proses tanya jawab. Model pembelajaran PP ini dipadukan dengan peta konsep (Model PP-peta konsep) agar siswa semakin aktif dan mampu membentuk pengetahuan mereka sendiri.

Pembelajaran dengan model Direct Instruction (DI) merupakan model pembelajaran yang berpusat pada guru yang berorientasi pada tujuan pembelajaran. Saat melaksanakan model pembelajaran DI, guru harus mendemonstrasikan pengetahuan dan keterampilan yang akan dialihkan kepada siswa, selangkah demi selangkah. (Siregar, 2010). Dalam model pembelajaran ini, guru memiliki peran yang sangat dominan, sehingga guru harus menjadi model yang menarik bagi siswa (Santoso, 2014).

Berdasarkan hasil penelitian yang dilakukan oleh Surpita (2009) pada pokok bahasan minyak bumi menunjukkan bahwa penerapan model pembelajaran PP dapat meningkatkan nilai rata-rata siswa sebesar $28,97 \%$ dan ketuntasan belajar meningkat sebesar 36,11 \%. Setyoningsih (2011) menyatakan bahwa penerapan model pembelajaran PP pada pokok bahasan sistem reproduksi dapat memberikan peningkatan aktivitas sebesar $24,93 \%$ dan prestasi belajar siswa meningkat sebesar 38,89\%. Sedangkan hasil penelitian model pembelajaran DI dilakukan oleh Santosa \& Hartati (2014) menyatakan bahwa ada pengaruh model pembelajaran DI terhadap hasil belajar sebesar 61,34\%. Zahriani (2014) menyatakan bahwa model pembelajaran DI relevan digunakan untuk pembelajaran sains pada materi yang menjelaskan konsep dan prosedural.

Peta konsep merupakan media pendidikan yang dapat menunjukkan konsep ilmu yang sistematis, yaitu dimulai dari inti permasalahan sampai pada bagian pendukung yang mempunyai hubungan satu dengan lainnya, sehingga dapat membentuk pengetahuan dan mempermudah pemahaman suatu topik pelajaran (Situmorang, 2010). Untuk membuat media peta konsep, harus ditentukan dulu konsep utama, yang disebut pusat konsep. Berikutnya menentukan konsep-konsep pendukung lainnya yang diorganisasikan secara baik dengan memilih kata, istilah dan rumus atau ungkapan tertentu yang memiliki arti dan mempunyai hubungan terhadap konsep utama. Hubungan ini dapat berbentuk hubungan hirarkial (ke atas dan ke bawah) atau hubungan horizontal (klasikal) (Tambunan dan Simanjuntak, 2010). Peta konsep dapat berbentuk pohon jaringan (network tree), rantai kejadian (events chains), konsep siklus (cycle consept) dan peta konsep laba-laba (spider concept map) (Milfayetty, dkk., 2011). Pembelajaran dengan bantuan peta konsep merupakan salah satu cara agar siswa lebih mudah menemukan konsep materi yang harus dikuasai. Kajian peta konsep dimulai dari inti permasalahan sampai pada bagian pendukung yang mempunyai hubungan satu dengan lainnya, sehingga dapat membentuk pengetahuan dan mempermudah pemahaman materi pelajaran (Anwar, 2011) 
Dalam proses belajar mengajar kehadiran media peta konsep mempunyai arti yang cukup penting karena ketidakjelasan bahan yang disampaikan dapat dibantu dengan menghadirkan media peta konsep sebagai perantara untuk memahami mataeri yang disampaikan. Kerumitan bahan yang akan disampaikan kepada anak didik dapat disederhanakan dengan bantuan media peta konsep (Holil, 2008). Media dapat mewakili apa yang kurang mampu guru ucapkan melalui kata-kata atau kalimat tertentu.

Hidrokarbon merupakan materi yang memerlukan kecakapan, keterampilan, pengetahuan konsep yang tinggi serta kemampuan berpikir yang kritis dalam menyelesaikan permasalahan yang berkaitan dengan materi tersebut, sehingga guru dituntut untuk meningkatkan kualitas pembelajarannya guna meningkatkan aktivitas dan prestasi belajar siswa.

Penelitian ini mengkaji tentang peranan model pembelajaran Probing prompting (PP) dan Direct Instruction (DI) yang dilengkapi dengan media peta konsep pada materi hidrokarbon.

\section{Metode Penelitian}

Penelitian ini adalah penelitian quasi eksperimen. Populasi penelitian ini adalah seluruh siswa kelas $X$ SMA Negeri 10 yang terdiri dari 6 kelas. Sampel penelitian dilakukan dengan random sampling sebanyak dua kelas. Dimana kelas pertama dijadikan kelas eksperimen dengan menggunakan model pembelajaran probing-prompting (PP) dan kelas kedua sebagai kelas kontrol dengan pembelajaran Direct Instruction (DI). Kedua kelas menggunakan media peta konsep, dan Jumlah siswa sebanyak 35 orang untuk setiap kelas. Desain penelitian yang digunakan adalah two group pretest-posttest design.

Penelitian diawali penyusunan instrumen penelitian yang terlebih dahulu diuji validitas, reliabilitas, tingkat kesukaran dan daya pembeda. Tahap berikutnya adalah melakukan pre-test pada kedua kelas yang bertujuan mengetahui kemampuan awal siswa. Setelah kedua kelas homogen maka selanjutnya melakukan proses pembelajaran dengan model pembelajaran probingprompting menggunakan media peta konsep pada kelas eksperimen dan pengajaran dengan model pembelajaran Direct Instruction menggunakan media peta konsep pada kelas kontrol. Tahap akhir adalah posttest pada kelas eksperimen dan kelas kontrol untuk mengetahui hasil belajar siswa setelah perlakuan yang diberikan. Data pretest dan posttest dianalisis sehingga diperoleh kesimpulan. Analisis data dilakukan dengan tahapan uji normalitas, uji homogenitas dan uji hipotesis dengan uji t pihak kanan.

\section{Hasil Penelitian dan Pembahasan}

Data yang diperoleh adalah data tes awal (pretest), yang diberikan sebelum perlakuan, dan tes akhir (posttest) yang diberikan setelah perlakuan pada masingmasing kelas eksperimen dan kontrol. Tes awal (pretest) bertujuan untuk mengetahui kemampuan awal siswa pada materi senyawa hidrokarbon, sedangkan tes akhir (posttest) bertujuan untuk mengetahui hasil belajar masing-masing kelas sampel yang diberikan perlakuan berbeda. Peningkatan nilai pretest dan post-test digunakan untuk mengetahui persen peningkatan hasil belajar sebelum dan setelah diberikan perlakuan terhadap kelas eksperimen dan kelas kontrol. Hasil perolehan rata-rata pretest dan posttest disajikan pada tabel 1.

Hasil belajar siswa pada pokok bahasan senyawa hidrokarbon dengan menerapkan model pembelajaran probing-prompting menggunakan media peta konsep lebih tinggi daripada hasil belajar siswa dengan model pembelajaran Direct Instruction dengan menggunakan media peta konsep. Hal ini dapat dilihat dari hasil pencapaian rata-rata nilai eksperimen $(37,20$ dan 71,29$)$ dan persen peningkatan hasil belajar (54,28 \%), sedangkan pencapaian rata-rata nilai kontrol 
$(39,76$ dan 66,47$)$ dan persen peningkatan hasil belajar (44,34 \%).

Tabel 1. Data Deskriptif Nilai Pretest dan Posttest

\begin{tabular}{ccc}
\hline \multirow{2}{*}{ Jenis Data } & \multicolumn{2}{c}{ Kelas Sampel } \\
\cline { 2 - 2 } & $\begin{array}{c}\text { Kelas } \\
\text { Eksperimen }\end{array}$ & $\begin{array}{c}\text { Kelas } \\
\text { Kontrol }\end{array}$ \\
\hline Pre-test & & \\
$\bar{x}$ & 37,20 & 39,76 \\
S & 7,87 & 9,69 \\
S$^{2}$ & 61,93 & 93,90 \\
\hline Pre-test & & \\
$\bar{x}$ & 71,29 & 66,47 \\
S & 10,95 & 8,91 \\
S$^{2}$ & 119,80 & 79,38 \\
\hline Peningkatan & $54,28 \%$ & $44,34 \%$ \\
Nilai & &
\end{tabular}

Keterangan :

$\begin{array}{lll}\bar{x} & \text { : Nilai rata-rata } & \\ \mathrm{S} & \text { : Standar Deviasi } \\ \mathrm{S}^{2} & \text { : Varian } & \\ \mathrm{Uji} & \text { normalitas yang digunakan }\end{array}$
adalah dengan uji Chi Kuadrat dengan taraf signifikansi $\alpha=0,05$ dan $\mathrm{db}=5$. Kriteria pengujian yang digunakan yaitu jika $\chi^{2}$ hitung $<$ $\chi^{2}$ tabel, maka data nilai tersebut berdistribusi normal. Setelah dilakukan uji normalitas, diperoleh data seperti ditunjukkan pada tabel 2.

Tabel 2. Uji Normalitas

\begin{tabular}{lcccc}
\hline Data & \multicolumn{2}{c}{ Eksperimen } & Kontrol & \\
\cline { 2 - 5 } & $\chi^{2}{ }_{\text {hitung }}$ & $\chi^{2}$ tabel & $\chi^{2}$ hitung & $\chi^{2}$ tabel \\
\hline Pretest & 9,485 & 11,07 & 7,020 & 11,07 \\
\hline Posttest & 9,368 & 11,07 & 3,832 & 11,07 \\
\hline
\end{tabular}

Uji homogenitas bertujuan untuk mengetahui homogenitas sampel. Kriteria pengujian pada taraf signifikansi $\alpha=0,05$, yaitu jika nilai $F_{\text {hitung }}<$ Ftabel, maka dapat disimpulkan bahwa kelompok sampel berasal dari populasi yang homogen. Data uji homogenitas ditunjukkan tabel 3.

Tabel 3. Uji Homogenitas

\begin{tabular}{lcc}
\hline Data & Fhitung & Ftabel \\
\hline Pretest & 1,23 & 1,776 \\
\hline Posttest & 1,229 & 1,776 \\
\hline
\end{tabular}

Uji hipotesis ini bertujuan untuk mengetahui apakah Ha dalam penelitian diterima atau ditolak. Uji hipotesis yang dilakukan dalam penelitian ini adalah uji $\mathrm{t}$ satu pihak yaitu pihak kanan pada taraf signifikansi $\alpha=0,05$. Kriteria pengujian adalah Ha diterima jika thitung $>$ tabel. Hasil perhitungan uji hipotesis dapat dilihat pada tabel 4 .

Tabel 4. Uji hipotesis

\begin{tabular}{|c|c|c|c|}
\hline \multicolumn{2}{|c|}{ Data Kelas } & thitung & tabel \\
\hline Eksperimen & Kontrol & & \\
\hline $\bar{X}_{1}=71,29$ & $\overline{X_{2}}=66,47$ & & \\
\hline$S=10,95$ & $S=8,91$ & 6,418 & 1,997 \\
\hline$S^{2}=119,80$ & $S^{2}=79,38$ & & \\
\hline $\mathrm{n}_{1}=35$ & $\mathrm{n}_{2}=35$ & & \\
\hline
\end{tabular}

Hasil analisa data penelitian menunjukkan bahwa data berdistribusi normal dan sampel berasal dari populasi yang homogen. Hal ini berarti hasil yang diperoleh dalam penelitian dapat mewakili seluruh populasi. Data hasil uji hipotesis diperoleh thitung $(6,418)>$ tabel $(1,997)$, yang artinya Ha diterima dan Ho ditolak. Hasil uji hipotesis menunjukkan bahwa penerapan model pembelajaran probing-prompting dengan menggunakan media peta konsep (Model PP-peta konsep) dapat memberikan hasil belajar kimia siswa yang lebih tinggi dibandingkan dengan penerapan model pembelajaran Direct Instruction dengan menggunakan media peta konsep (Model DIpeta konsep) pada pokok bahasan senyawa hidrokarbon.

Data yang dapat memperkuat penerimaan Ha ini dapat dilihat dari hasil belajar siswa baik di kelas eksperimen maupun kelas kontrol. Kelas eksperimen memiliki nilai rata-rata pre-test $=37,20$ dan nilai rata-rata post-test $=71,29$ dengan persen peningkatan hasil belajar sebesar $54,28 \%$, sedangkan kelas kontrol memiliki nilai ratarata pre-test $=39,76$ dan nilai rata-rata posttest $=66,47$ dengan persen peningkatan hasil belajar sebesar $44,34 \%$. Hal ini menunjukkan bahwa model pembelajaran PP-peta konsep memberikan persen peningkatan hasil belajar $9,94 \%$ lebih tinggi daripada model 
pembelajaran DI-peta konsep pada pokok bahasan hidrokarbon.

Beberapa hal yang terjadi didalam kelas yang menyebabkan selisih persen peningkatan hasil belajar 9,94\% adalah ketidakberanian siswa mengemukakan pendapatnya, baik dalam bentuk pertanyaan ataupun jawaban. Selain itu, jumlah siswa yang cukup banyak menyita banyak waktu untuk memberikan pertanyaan kepada setiap siswa.

Penggunaan model pembelajaran yang berbeda dengan media pembelajaran yang sama di kedua kelas (eksperimen dan kontrol) menjadi dasar perbedaan kemampuan yang diperoleh siswa dalam pembelajaran. Namun kreativitas seorang guru dalam menciptakan pembelajaran yang benar-benar menarik, nyaman, menyenangkan, dan berkualitas dapat menumbuhkan minat dan motivasi belajar sehingga hasil belajar menjadi lebih baik.

Berdasarkan hasil temuan di lapangan, penerapan model pembelajaran probing-prompting dengan menggunakan media peta konsep (Model PP-peta konsep) sangat membantu dalam peningkatan hasil belajar siswa. Model pembelajaran ini sesuai digunakan untuk menjelaskan pokok bahasan hidokarbon karena dengan pembelajaran ini mendorong siswa berfikir kreatif dengan menghubungkan materi yang sudah dikuasai dengan materi yang sedang dipelajari. Model ini juga mengembangkan keberanian dan keterampilan siswa dalam menjawab dan mengemukakan pendapat, sehingga pengetahuan benar-benar dibentuk dalam diri siswa dan proses pembelajaran mengarahkan siswa menjadi aktif. Hal ini terlihat dari antusias siswa dalam menanggapi pertanyaan ataupun memberikan pertanyaan pada tahap presentasi/ penyajian hasil dalam proses pembelajaran.

\section{Simpulan dan Saran}

Berdasarkan hasil pengolahan data dan analisis data dalam penelitian, maka disimpulkan bahwa hasil belajar siswa yang diajarkan dengan model pembelajaran probing-prompting menggunakan media peta konsep (Model PP-peta konsep) lebih tinggi dibandingkan dengan siswa yang diajarkan dengan model pembelajaran Direct Instruction menggunakan media peta konsep (Model DIpeta konsep) pada pokok bahasan senyawa hidrokarbon di SMA Negeri 10 Medan. Selain itu persen peningkatan hasil belajar siswa yang diberikan model pembelajaran prompting menggunakan media peta konsep (Model PPpeta konsep) sebesar 54,28\%, lebih tinggi $9,94 \%$ dibandingkan dengan siswa yang diajarkan dengan model pembelajaran Direct Instruction menggunakan media peta konsep (Model DI-peta konsep) sebesar 44,34 \%.

\section{Daftar Pustaka}

Anwar., (2011)., Peta konsep Untuk Belajar Bermakna., http://sman1kobi.sch.id/ diunduh tanggal 9 Maret 2011.

Arikunto, S., (2009), Dasar-dasar Evaluasi Pendidikan, Edisi Revisi, Penerbit Bumi Aksara, Jakarta.

Astuti, P., (2011), Model Pembelajaran Probing Prompting, Universitas Negeri Malang, Jawa Timur.

Huda, M., (2014), Model-model Pengajaran dan Pembelajaran, Pustaka Pelajar, Yogyakarta.

Djamarah, S.B., dan Zain, A., (2006), Strategi Belajar Mengajar, Edisi Revisi, Penerbit Rineka Cipta, Jakarta.

Fitroh, K.M., (2012), Pengaruh Model Pembelajaran Teknik Probing Prompting Terhadap Pemahaman Konsep dan Keterampilan Siswa Kelas VIII MTsN Langkapan Blitar, Skripsi, IAIN Tulungagung, Jawa Timur.

Holil, A., (2008)., Peta Konsep Untuk Mempermudah Konsep Sulit dalam Pembelajaran., http://anwarholil.blogspot.com/ diunduh tanggal 17 November 2015

Milfayetty, S., dkk., (2011), Psikologi Pendidikan, Penerbit Pascasarjana Unimed, Unimed. 
Pristiadiutomo, (2010), Model - model Pembelajaran,

http://pristiadiutomo.blog.co.uk/2010/ 09/02/model-model-pembelajaran9297440/., diakses 24 Februari 2015.

Sagala, S., (2003), Konsep dan Makna Pembelajaran Untuk Membantu Memecahkan Problematika Belajar dan Mengajar, Penerbit Alfabeta, Bandung.

Santosa, H., \& Hartati, S.C.Y., (2014)., Penerapan Model Pembelajaran Direct Instruction Terhadap Hasil Belajar Pukulan Pencak Silat Pada Pembelajaran Pendidikan Jasmani, Olahraga, Olah raga dan Kesehatan., Jurnal Pendidikan Olah Raga dan Kesehatan., 2 (1) :293-296.

Setyoningsih, D., (2011), Pengaruh Penerapan Metode Probing Prompting dengan Complete Sentence terhae-Jourap Kualitas Belajar Siswa pada Materi Sistem Reproduksi di SMAN 1 Juwana, Skripsi, Universitas Negeri Semarang.

Siregar, L., (2009), Penerapan Pembelajaran Konstruktivisme Dengan Metode Penugasan Di Sekolah Dan Penugasan Di Rumah Pada Pokok Bahasan Senyawa Hidrokarbon Di SMAN 2 Medan T.A 2008/2009, Skripsi, FMIPA, Unimed, Medan.
Situmorang, M., (2010), Penelitian Tindakan Kelas (PTK) Untuk Mata Pelajaran Kimia, Penerbit Unimed, Medan.

Surpita, Y., (2009), Penerapan Pendekatan Konstruktivisme Model Pembelajaran Kooperatif Tipe Probing-Prompting Untuk Meningkatkan Hasil Belajar Kimia Pokok Bahasan Minyak Bumi Di Kelas X Siswa MAN, skripsi, Bandung.

Tambunan, M.M., dan Simanjuntak, A., (2010), Strategi Belajar Mengajar, Penerbit FMIPA Unimed, Medan.

Widyastuti, D.A., Ganing, N. N., \& Ardana, I.K., (2014), Penerapan Model Pembelajaran Probing Prompting Untuk Meningkatkan Prestasi Belajar IPA, e-Journal Mimbar PGSD Undiksha, 2(1).

Zahriani., (2014)., Kontekstualisasi Direct Instruction dalam Pembelajaran Sains., Lantanida Journal., 1(1) : 95-106. 